\title{
Suturing intraabdominal organs: when do we cause tissue damage?
}

\author{
Sharon P. Rodrigues • Tim Horeman • \\ Jenny Dankelman • John J. van den Dobbelsteen • \\ Frank-Willem Jansen
}

Received: 18 April 2011 / Accepted: 4 October 2011/Published online: 25 October 2011

(C) The Author(s) 2011. This article is published with open access at Springerlink.com

\begin{abstract}
Background It is generally assumed that safety of tissue manipulations during (laparoscopic) surgery is related to the magnitude of force that is exerted on the tissue. To provide trainees with performance feedback about tissuehandling skills, it is essential to define objective criteria for judging the safety of applied forces. To be of clinical relevance, these criteria should relate the applied forces to the risk of tissue damage. This experimental study was conducted to determine which tractive forces during suturing cause tissue damage in different types of porcine tissues. Methods Tractive forces were applied on eight different tissue types (fascia, aorta, vena cava, peritoneum, small and large bowel, uterus, and fallopian tube) of 10 different pigs by placing increasingly higher loads on sutures in the tissue. We determined the load at what tissue damage occurred through visual inspection of the tissue. For each tissue sample, three consecutive measurements were performed.

Results The average maximum acceptable force varied between $11.43 \mathrm{~N}$ for fascia to $1.25 \mathrm{~N}$ for fallopian tube. The difference in allowable force between these two structures is almost tenfold. Small bowel can be handled
\end{abstract}

Sharon P. Rodrigues and Tim Horeman have contributed equally to the manuscript.

S. P. Rodrigues - T. Horeman · F.-W. Jansen

Department of Gynecology, Leiden University Medical Center, Leiden, The Netherlands

T. Horeman $(\bowtie) \cdot$ J. Dankelman · J. J. van den Dobbelsteen .

F.-W. Jansen

Department of BioMechanical Engineering,

Faculty of Mechanical, Maritime and Materials Engineering

(3 mE), Delft University of Technology, Mekelweg 2,

2628 CD Delft, The Netherlands

e-mail: T.Horeman@tudelft.nl with a tractive force almost 1.5-fold higher than large bowel.

Conclusions Each tissue type was found to have its own individual range of acceptable maximum forces before visual tissue damage occurs. With the results presented in this study, it is possible to provide clinically relevant and validated feedback to trainees about their tissue-handling skills.

Keywords Tissue properties · Force measurements · Forces · Suturing - Surgery · Tissue damage .

Force feedback

It is well established that basic surgical skills should preferably be trained in a nonclinical setting [1-3]. Especially complex surgical tasks such as those performed in laparoscopic procedures place higher demands on the motor skills of the surgeon and require extensive training. This training can be done in box or virtual-reality trainers or pig models and is currently mainly focused on time and economy of movement. In clinical practice, the gold standard is to manipulate tissue as gently as possible and only if necessary, because every manipulation or dissection creates tissue reaction. However, the loss of haptic feedback in minimally invasive surgery (MIS), due to resistance inside the trocars and the use of long laparoscopic instruments, hinders the estimation of applied forces in instrument-tissue interaction [4, 5]. This problem translates, for example, into more difficulties when learning to safely apply force in a laparoscopic grasp than to learn the same with barehanded lifts [6]. To facilitate training of tissue-handling skills, a force measurement platform has been developed for the box trainer [7]. This force platform provides the trainee with objective feedback of the forces 
applied on tissue during a suture task. The pilot study of this article suggested that a novice can apply forces up to $7 \mathrm{~N}$ during needle driving [7]. However, information about the applied forces does not have any clinical relevance if not related to in vivo tissue damage. The current study was conducted to determine the difference in strength for different types of fresh post mortem porcine tissue when tractive forces are applied on a single suture.

\section{Methods}

The amount of tractive force on a suture that causes visually detectable tissue damage was investigated in eight different types of porcine tissue (fascia, aorta, vena cava, peritoneum, small and large bowel, uterus, and fallopian tube) in 10 different pigs. All porcine tissues were acquired from a slaughterhouse on request and immediately stored in physiologic saline solution at maximum temperature of $7^{\circ} \mathrm{C}$ to conserve the tissue until the measurements were performed. Measurements were performed within $6 \mathrm{~h}$ after slaughter.

An experimental setup was built to apply tractive forces on a suture (Fig. 1). With this setup, tractive forces up to a maximum of $13 \mathrm{~N}$ could be placed on the suture by means of adding weights of $50 \mathrm{~g}$ (approximately $0.5 \mathrm{~N}$ ) in gradual load steps. During every load step tractive force was applied for $1 \mathrm{~min}$. Between load steps, the tissue was completely relieved of tractive force before the next load step was examined (i.e., another $50 \mathrm{~g}$ was added). To minimize the influence of friction in the experimental setup, the cable was guided by two pulleys with special low-friction bearings. The example in Fig. 2 shows the force and rupture graph of a force measurement on a single tissue sample of large intestine.
Before the measurements started, tissue was prepared and fixed to a plateau (Fig. 1A), meaning that an ample size tissue sample was taken and hollow structures (aorta, vena cava, bowel, etc.) were cut open and laid flat on the plateau. During opening of the hollow structures (i.e., aorta, vena cava, bowel), the tissue in the suture area was not stretched or grasped to prevent changes in the force characteristics of the tissue. While fixing tissue samples to the plateau, irregularities in the folding of the tissue were smoothened out without causing tissue damage. Once the tissue sample was fixed to the plateau, it was moistened throughout the measurement with physiologic saline solution (similar to that in which it had been stored) to prevent dehydration. Vicryl 3-0 suture packs of Ethicon (with 26-mm round needle) were used to suture. Every suture was placed on a homogeneous part

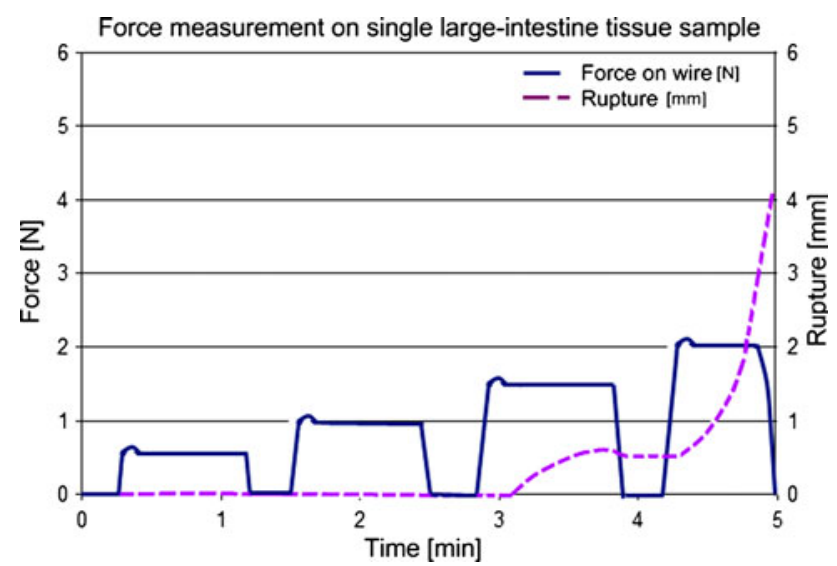

Fig. 2 Representation of a force measurement as performed on a single tissue sample of large intestine. As the force on the wires increases after each load step, the tissue finally starts to rupture during the third step. During the fourth step, the rupture speed exceeds $2 \mathrm{~mm} / \mathrm{min}$ and the measurement is finished
Fig. 1 Tissue measurement system built for tractive force measurements. Tissue can be fixed on the plateau (A). Example of how the suture width (B) and height $(\mathbf{C})$ are standardized before the force measurement starts
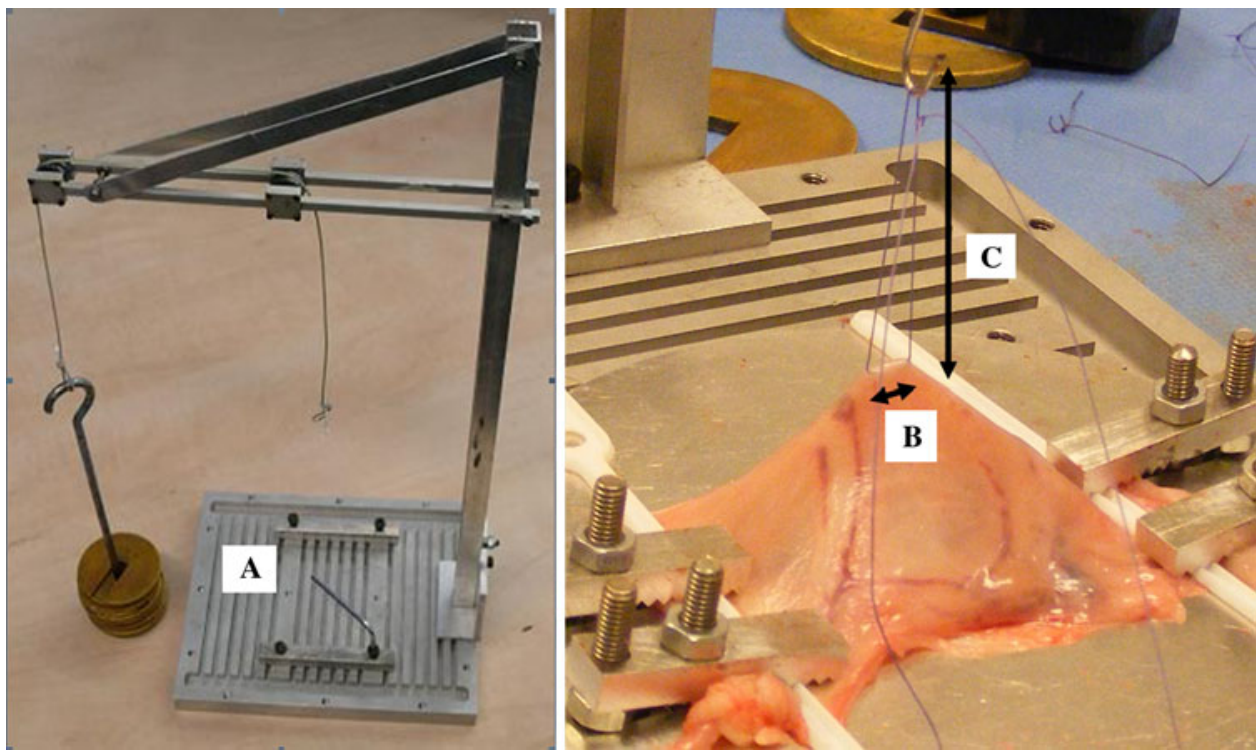
of the tissue sample, and irregularities such as small blood vessels and fibroid tissue were avoided as much as possible. Three tractive force measurements were performed on every tissue sample. Between two separate measurements a minimum distance of $20 \mathrm{~mm}$ was kept so that damage which originated from prior measurements did not influence the current measurement. The distance between the insertion and exit point of the needle was $8 \mathrm{~mm}$ at minimum and $11 \mathrm{~mm}$ at maximum (Fig. 1B). The two wires of the suture were knotted at a minimum distance of $50 \mathrm{~mm}$ measured from the tissue to the knot (Fig. 1C). For every measurement two values were registered:

(1) The mass of the load at which the first sign of macroscopic damage was noted.

(2) The mass of the load at which the tissue sample started to rupture; rupture was defined as the insertion or exit hole of the suture becoming larger at a speed of $2 \mathrm{~mm} / \mathrm{min}$.

All measurements were done by two investigators. If one investigator could not clearly determine whether tissue damage started to occur, the other investigator was consulted and a consensus was reached after applying further load steps. In ambiguous cases a blue light was lit underneath the tissue. Using this approach, tissue damage such as small punctures could reliably be detected through visual inspection (Fig. 1). A control group was created to determine whether consecutive load steps on one suture during a single measurement would weaken the tissue at the entry and exit point of the suture and therefore influence the results. The control group consisted of two separate control measurements performed on every tissue type. For the control measurements, tissues were prepared similarly to the regular measurements. Sutures were also placed with Vicryl 3-0 packs of Ethicon and in a similar manner to the regular measurements. In contrast to the regular measurements, in the control measurements, each tissue sample was loaded only once. For each of the eight tissue types, the first tissue sample was loaded with the maximum load as found in the regular measurement with an additional $200 \mathrm{~g}$. For each following new tissue sample, the total load was decreased by $50 \mathrm{~g}$. The measurements with decreasing load were repeated until no tissue damage was noticed anymore. For every measurement, the number of millimeters (starting with $3 \mathrm{~mm}$ ) of rupture was registered.

\section{Results}

The mean tractive force and $95 \%$ confidence intervals $(\mathrm{CI})$ for each of the different types of porcine tissue are displayed in Table 1. Figure 3 shows boxplots of the tractive forces at the first sign of tissue damage and moment of rupture.
Table 1 Tissue damage after loading

\begin{tabular}{|c|c|c|c|c|c|}
\hline \multirow[t]{2}{*}{ Tissue type } & \multirow[t]{2}{*}{$N$} & \multicolumn{2}{|c|}{ First sign of damage } & \multicolumn{2}{|l|}{ Rupture } \\
\hline & & $\begin{array}{l}\text { Mean } \\
\text { mass }(\mathrm{g})\end{array}$ & $95 \%$ CI & $\begin{array}{l}\text { Mean } \\
\text { mass }(g)\end{array}$ & $95 \%$ CI \\
\hline Fascia & 30 & 1,143 & $1,070-1,216$ & 1,183 & $1,120-1,247$ \\
\hline Aorta & 30 & 987 & $911-1,062$ & 1,107 & $1,044-1,170$ \\
\hline Vena cava & 30 & 523 & $464-583$ & 637 & $555-718$ \\
\hline Peritoneum & 30 & 187 & $163-211$ & 233 & $202-265$ \\
\hline $\begin{array}{l}\text { Large } \\
\text { bowel }\end{array}$ & 30 & 158 & $136-180$ & 212 & $188-236$ \\
\hline $\begin{array}{l}\text { Small } \\
\text { bowel }\end{array}$ & 30 & 218 & $196-241$ & 300 & $274-326$ \\
\hline Uterus & 30 & 297 & $263-331$ & 365 & $332-398$ \\
\hline $\begin{array}{l}\text { Fallopian } \\
\text { tube }\end{array}$ & 30 & 125 & $101-149$ & 168 & $147-189$ \\
\hline
\end{tabular}

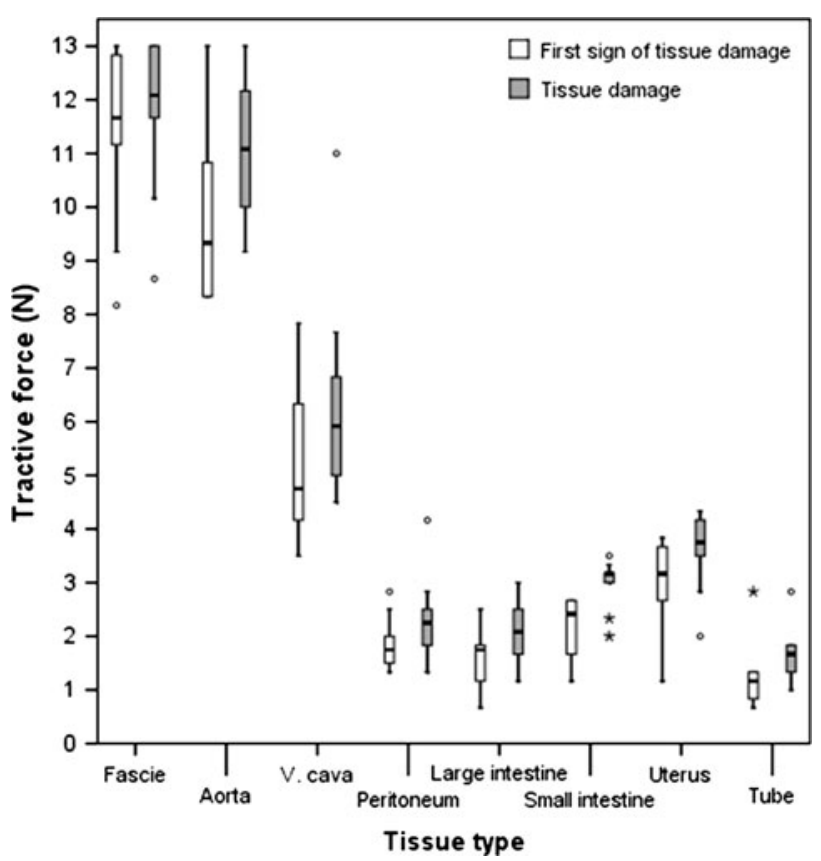

Fig. 3 Boxplots of the tractive force measurements at the first sign of tissue damage and moment of rupture. For each box, the central mark is the median, the edges of the box are the 25th and 75th percentiles, the whiskers extend to the most extreme data points the algorithm considers not to be outliers, and the outliers are plotted individually as open circles if the value exceeds $\sigma$ and asterisks if the value exceeds $2 \sigma$

Before tissue damage occurred, the highest tractive force could be put on fascia and the lowest tractive force on fallopian tube. The difference in allowable force between these two structures is almost tenfold. Small bowel can be handled with a tractive force almost 1.5-fold higher than large bowel. 
Table 2 Tissue damage after loading: control measurements

\begin{tabular}{llrl}
\hline Tissue & Measurement & $\begin{array}{l}\text { Mass }(\mathrm{g}) \text { tissue } \\
\text { damage }\end{array}$ & $\begin{array}{l}\text { Mass }(\mathrm{g}) \text { no tissue } \\
\text { damage }\end{array}$ \\
\hline Fascia & 1 & 1,300 & 1,200 \\
& 2 & 1,300 & 1,200 \\
Aorta & 1 & 800 & 700 \\
& 2 & 1,000 & 800 \\
Vena cava & 1 & 500 & 400 \\
& 2 & 600 & 500 \\
Peritoneum & 1 & 200 & 100 \\
& 2 & 150 & 100 \\
Large & 1 & 300 & 200 \\
bowel & 2 & 200 & 100 \\
Small & 1 & 300 & 200 \\
bowel & 2 & 350 & 300 \\
Uterus & 1 & 300 & 250 \\
& 2 & 500 & 400 \\
Fallopian & 1 & 100 & 50 \\
tube & 2 & 150 & 50 \\
\hline
\end{tabular}

The results of the control measurements (Table 2) were comparable to the results obtained when instantly loading the tissue with different masses. These results suggest that consecutive load steps on one suture during a single measurement do not weaken the tissue at the entry or exit point of the suture.

\section{Discussion}

Each tissue type was found to have its own individual range of acceptable maximum forces before visual tissue damage occurred. The variation of the results was relatively small within individual types of tissue, being around one load step for peritoneum, large and small bowel, uterus, and fallopian tube and around two or three load steps for vena cava, aorta, and fascia. The observed variance in the measurements is presumably mainly due to natural variation between different pigs and tissue samples. As such, the presented data can be used to determine thresholds for feedback about applied forces. With these thresholds, trainees can be provided with clinically relevant information about their performance and use this feedback to adjust their strategy in (laparoscopic) suturing in different type of tissue, therefore mimicking the issue of tissue handling. An earlier study showed the development of a laparoscopic training system that visualizes the interaction force during a suture task as a colored three-dimensional (3D) arrow on a monitor [8]. In this particular surgical trainer the data could be used to warn the resident/ student in real time if safety thresholds are exceeded during needle driving or knot tying.
Previous studies have investigated tissue damage due to grasping forces $[9,10]$ and compression loads in porcine [11] and human organs [12]. However, tissue damage due to tractive force on sutures has not been studied before. Heijnsdijk et al. [9] studied tissue damage as a result of the pulling forces exerted on porcine bowels using various grasping forceps. The allowable forces reported in that study were higher than found in the current study. This is possibly due to the larger contact area of grasping forceps compared with the contact area of the sutures, so that the forces are distributed across a larger part of the tissue. In this study, tractive forces on sutures were investigated because suturing is one of the most critical aspects of safe tissue handling, and knowledge about allowable forces while suturing is therefore crucial.

A limitation of this study is, however, the use of fresh post mortem porcine tissues. The porcine model was chosen because it is often used as a training model in surgery. Furthermore, porcine bowel (large and small) has been shown to have comparable tissue characteristics to human bowel [9]. Although the tissue was freshly obtained, post mortem degradation of tissue takes place and could weaken the tissue and to some degree influence our results [11]. The influence of degradation was kept to a minimum by storing the tissue in physiologic saline solution at a maximum temperature of $7^{\circ} \mathrm{C}$ and performing the measurements within $6 \mathrm{~h}$ after slaughter. Another limitation of using post mortem tissue is that there is no bleeding. Whereas bleeding normally is one of the first signs of tissue damage, the investigators in this study depended on macroscopic enlargement of the puncture holes. Although it was attempted to determine tissue damage as precisely as possible, by judgment of two investigators and use of facilitating tools such as the blue light (Fig. 1), it cannot be guaranteed that certain microscopic tissue damage had not already occurred. In fact it is quite plausible that microscopic tissue damage precedes macroscopic tissue damage and that microscopic tissue changes could occur before the load step at which macroscopic tissue damage was noted. However, during surgery, the surgeon also depends on visual judgment of macroscopic changes of the tissue to determine tissue damage, therefore the method used in this study approaches the clinical setting as much as possible.

The measurements were done in load steps with a maximum applied force of $13 \mathrm{~N}$. In some cases, especially with the fascia and aorta measurements, damage did not occur even at the load step of $13 \mathrm{~N}$. Hence, the tissue can take on forces above $13 \mathrm{~N}$ without the occurrence of macroscopic tissue damage. Because it was determined beforehand that forces above $13 \mathrm{~N}$ are not applicable for the training setup, the measurement stopped at $13 \mathrm{~N}$. This distorts the mean and median results for fascia and aorta, for which the true mean and median values could lie above 
those given in the presented results. However, this should not be a problem for the thresholds in the proposed training program, as training of tissue handling will logically be done with thresholds that lie much lower, such as those of large/small bowel, uterus, fallopian tube, or peritoneum.

In this study, the load on the tissues was slowly increased by hand until the tissue was carrying the load on its own (Fig. 2). This way of tissue loading is different from a fast short jerk on the suture wires. During a fast jerk, the moving instruments and surgeon's arms are instantly stopped by the tensioned wires. This fast deceleration of mass results in very short-lasting but high reaction forces in the suture and tissue. Further studies are necessary to determine whether the threshold values found after a slowly increasing load resemble threshold values found after a fast increasing load.

\section{Conclusions}

It is evident that training of tissue-handling skills in a nonclinical setting is crucial for patient safety. The presented data can be used to establish safety thresholds in skills training models (box trainer) that provide force feedback to the trainee during a suture tasks. With the determined safety thresholds it becomes possible to teach the resident/student to link the disturbed force feedback at the instrument handles to visually perceived tissue deformation.

Acknowledgments The authors would like to thank Gertjan Hultzer and René Rodenburg from the skills lab of the Leiden University Medical Center for providing all necessary facilities to perform this study.

Disclosures Authors Sharon P. Rodrigues, Tim Horeman, FrankWillem Jansen, Jenny Dankelman, and John J. van den Dobbelsteen have no conflicts of interest or financial ties to disclose.

Open Access This article is distributed under the terms of the Creative Commons Attribution Noncommercial License which permits any noncommercial use, distribution, and reproduction in any medium, provided the original author(s) and source are credited.

\section{References}

1. Seymour NE, Gallagher AG, Roman SA, O'Brien MK, Bansal VK, Andersen DK et al (2002) Virtual reality training improves operating room performance: results of a randomized, doubleblinded study. Ann Surg 236(4):458-463

2. Grantcharov TP, Kristiansen VB, Bendix J, Bardram L, Rosenberg J, Funch-Jensen P (2004) Randomized clinical trial of virtual reality simulation for laparoscopic skills training. Br J Surg 91(2): 146-150

3. Scott DJ, Bergen PC, Rege RV, Laycock R, Tesfay ST, Valentine RJ et al (2000) Laparoscopic training on bench models: better and more cost effective than operating room experience? J Am Coll Surg 191(3):272-283

4. van den Dobbelsteen JJ, Schooleman A, Dankelman J (2007) Friction dynamics of trocars. Surg Endosc 21(8):1338-1343

5. Bholat OS, Haluck RS, Murray WB, Gorman PJ, Krummel TM (1999) Tactile feedback is present during minimally invasive surgery. J Am Coll Surg 189(4):349-355

6. Westebring-van der Putten EP, van den Dobbelsteen JJ, Goossens RH, Jakimowicz JJ, Dankelman J (2009) Effect of laparoscopic grasper force transmission ratio on grasp control. Surg Endosc 23(4):818-824

7. Horeman T, Rodrigues SP, Jansen FW, Dankelman J, van den Dobbelsteen JJ (2010) Force measurement platform for training and assessment of laparoscopic skills. Surg Endosc 24(12): 3102-3108

8. Horeman T, Rodrigues SP, van den Dobbelsteen JJ, Jansen FW, Dankelman J (2011) Visual force feedback in laparoscopic training. Surg Endosc. doi:10.1007/s00464-011-1861-4

9. Heijnsdijk EA, van der Voort M, de Visser H, Dankelman J, Gouma DJ (2003) Inter- and intraindividual variabilities of perforation forces of human and pig bowel tissue. Surg Endosc 17(12): 1923-1926

10. De S, Rosen J, Dagan A, Hannaford B, Swanson P, Sinanan M (2007) Assessment of tissue damage due to mechanical stresses. Int J Robot Res 26(11-12):1159-1171

11. Rosen J, Brown JD, De S, Sinanan M, Hannaford B (2008) Biomechanical properties of abdominal organs in vivo and postmortem under compression loads. J Biomech Eng 130(2): 021020

12. Snedeker JG, Barbezat M, Niederer P, Schmidlin FR, Farshad M (2005) Strain energy density as a rupture criterion for the kidney: impact tests on porcine organs, finite element simulation, and a baseline comparison between human and porcine tissues. J Biomech 38:993-1001 